\title{
Case report:Trans-papillary free stenting of the cystic duct and of the common bile duct in a double biliary ducts anastomoses of a right lobe living donor transplantation
}

\author{
Salvatore Gruttadauria ${ }^{1,2^{*}}$, Alessandro Tropea ${ }^{1}$, Duilio Pagano ${ }^{1}$, Sergio Calamia ${ }^{1}$, Calogero Ricotta ${ }^{1}$,
} Pasquale Bonsignore', Sergio Li Petri ${ }^{1}$, Davide Cintorino ${ }^{1}$ and Fabrizio di Francesco ${ }^{1}$

\begin{abstract}
Background: One of the major issues related to the living donor liver transplantation recipient outcome is still the high rate of biliary complication, especially when multiple biliary ducts are present and multiple anastomoses have to be performed.

Case presentation and conclusion: We report a case of adult-to-adult right lobe living donor liver transplantation performed for a recipient affected by alcohol-related cirrhosis with MELD score of 17. End-stage liver disease was complicated by refractory ascites, portal hypertension, small esophageal varices and portal gastropathy, hypersplenism, and abundant right pleural effusion. Here in the attached video we described the adult-to-adult LDLT procedures, where a right lobe with two biliary ducts draining respectively the right anterior and the right posterior segments has been transplanted. LDLT required a biliary reconstruction using the native cystic and common bile ducts stented trans-papillary with two 5 - French $6 \mathrm{~cm}$ long soft silastic catheter. None major complications were detected during post-operative clinical courses. Actually, the donor and the recipient are alive and well. The technique we describe in the video, allow to keep the biliary anastomoses protected and patent without having the risk of creating cholestasis and the need of invasive additional procedure. No living donor right lobe transplantation should be refused because of the presence of multiple biliary ducts.
\end{abstract}

Keywords: Liver transplantation, Living donor liver transplantation, Biliary anastomoses, Cystic duct

\section{Background}

Living donor liver transplantation (LDLT) is a useful tool to increase the donor pool, and this is particularly important in area of the word where deceased donor rate is low $[1,2]$.

\footnotetext{
*Correspondence: sgruttadauria@ismett.edu

${ }^{1}$ Department for the Treatment and Study of Abdominal Diseases and Abdominal Transplantation, IRCCS-ISMETT (Istituto Di Ricovero E Cura a Carattere Scientifico-Istituto Mediterraneo Per I Trapianti E Terapie ad alta specializzazione) UPMC (University of Pittsburgh Medical Center) Italy, Via E. Tricomi 5, 90127 Palermo, Italy

Full list of author information is available at the end of the article
}

One of the major issues related to the recipient outcome is still the high rate of biliary complication, which has been reported being present in one third up to $40 \%$ of the cases [3, 4].

Especially when multiple biliary ducts are present and multiple anastomoses have to be performed, the rate of donor turned down and the rate of biliary complications in the recipient are augmented $[5,6]$.

Ideally, duct-to-duct anastomoses should be preferred to a hepatico-jejunostomy [7] because of the more physiologic preservation of the bilio-enteric continuity, the faster and more simple surgical technique and the 
possibility to treat endoscopically complications after surgery [8].

In this setting the idea to use the cystic duct together with the right duct or the common hepatic duct has been used in right lobe living donor transplantation since many years [9] and many techniques have been reported [10].

Here in this video (Additional file 1: Video) we describe a case of adult-to-adult LDLT where a right lobe with two biliary ducts draining respectively the right anterior and the right posterior segments has been transplanted. Biliary reconstruction had been performed using the native cystic and common bile ducts stented trans-papillary with two 5- French $6 \mathrm{~cm}$ long soft silastic stents where multiple holes in both sides were shaped and both stents were not secured by sutures.

\section{Case presentation}

We report a 66-year-old male with well-controlled type 2 diabetes and a single previous episode of transient ischemic attack, who had been diagnosed with Child's B9 liver cirrhosis secondary to alcoholic abuse. His Model of End-stage Liver Disease (MELD) score was 17, and clinical condition was complicated by episodes of refractory ascites, portal hypertension recanalization of the umbilical vein associated with venous ectasias in the context of the rectus abdominis and with caput medusae, small esophageal varices, hypersplenism, and abundant right pleural effusion. For persistent ascites refractory to diuretic therapy, with necessity of several evacuative paracentesis, and difficult management of diuretic therapy for secondary renal insufficiency, he underwent to transjugular porto-systemic shunt (TIPS) placement on November 19, 2019. According to the Italian system of allocation, this value is the minimum score required to be transplanted [11], he was listed in our Center for an elective LDLT on July 21, 2020.

His 31 year-old son decided to be evaluated and, considering the proper donor/recipient match, he was listed as right hepatic lobe live donor. Donor and recipient's pre-operative live donation parameters are shown in Table 1. We have proceeded with LDLT surgery on September 22, 2020. The live donor surgical procedure consisted of an open right hepatectomy (Couinaud segment 5-8) and the recipient surgery was a liver transplant performed with the piggyback technique and total venovenous bypass. Imaging evaluation and surgical maneuvers concerning the techniques adopted are reported in the attached video. We performed a double biliary anastomosis (two ducts in the right hepatic graft) the first between the cystic duct of the recipient duct for the posterior segments with 6-0 polydioxanone protected by a 6 Fr sylastic stent, and the second anastomosis between the choledochus and the bile duct for the anterior segments with 6-0 polydioxanone protected by an 8 Fr sylastic stent. The diameter of the graft bile ducts was respectively 5 and $7 \mathrm{~mm}$. The total ischemic time of the graft was $120 \mathrm{~min}$.

Both donor and recipient surgical procedure were uneventful; the donor was discharged to home on postoperative day 9 without any complaints. Although the recipient's hospital course was complicated by right pleural effusion, which was treated with percutaneous transthoracic drainage, no major complications developed in the recipient and he was discharged home in good clinical condition after 3 weeks.

\section{Discussion and conclusion}

Biliary leak and biliary stricture are still a major concern after LDLT [12], however biliary complications seem do not worsen the overall survival after transplant which is otherwise impacted by other factor such as correct liver volume match, portal flow modulation and clinical nutritional status of the recipient [13].

Multiple biliary ducts draining the right lobe, nowadays detected in details by pre-operative magnetic resonance cholangiopancreatography (MRCP) have been considered an additional risk of serious complications in LDLT [14]. However, the presence of more than one duct should not contraindicate the use of a living donor right lobe graft [15].

Surgical expertise in this filed has now reached a level of evidence which permits a safe use of graft with biliary variants [16].

The duct-to-duct biliary reconstruction has shown to be associated with more biliary stricture when compared with hepatico-jejunstomy but less biliary leak and overall seems to be the preferred method of biliary restoration in LDLT [17-19]. Mucosa to mucosa approximation with fine absorbable suture, with or without stenting according to the surgeon's discretion have been historically reported [20]. Moreover, much debate exists regarding the use of trans-anastomotic stents as well as the length of time the stent should be left in place [21-23]. In this scenario, the analysis of the literature recommend a selective approach to stent placement based on the diameter and the number of the ducts to be anastomosed [5].

In our experience regardless the health of the tissues we now routinely use stents in LDLT, and lately, as described in this video, our technique shifted towards the use of a $6 \mathrm{~cm}$ long, soft 5 French silastic stent left into the duodenum through the papilla. The patients usually eliminate spontaneously those stents within 6 weeks from surgery. If cholangitis would appear the endoscopic treatment may be performed and the stent removed [24-28]. 
Table 1 Pre-transplantation anthropometric, biochemical, and volumetric data of the donor and the recipient are reported

\begin{tabular}{|c|c|c|}
\hline \multicolumn{3}{|l|}{ Donor } \\
\hline Age: 31 years & Height: & $169 \mathrm{~cm}$ \\
\hline \multirow[t]{2}{*}{ Gender: Male } & Weight: & $76.8 \mathrm{~kg}$ \\
\hline & BMI & $27 \mathrm{~kg} / \mathrm{m}^{2}$ \\
\hline Age: 66 y & Height: & $168 \mathrm{~cm}$ \\
\hline \multirow[t]{2}{*}{ Gender: Male } & Weight: & $65 \mathrm{~kg}$ \\
\hline & BMI: & $23 \mathrm{~kg} / \mathrm{m}^{2}$ \\
\hline \multicolumn{3}{|l|}{ Clinical picture: } \\
\hline Diagnosis: Alcohol-related cirrhosis & MELD: & 17 \\
\hline Symptoms: Refractory ascites & CTP: & B 9 \\
\hline Previous surgery: None & Platelets: & $95,000 / u L$ \\
\hline Portal vein thrombosis: None & Max spleen diameter: & $15 \mathrm{~cm}$ \\
\hline \multirow[t]{4}{*}{ Radiologic (CT) donor liver volumetry: } & Whole liver: & $1478 \mathrm{~cm}^{3}$ \\
\hline & Right lobe: & $879 \mathrm{~cm}^{3}$ \\
\hline & Left lobe: & $599 \mathrm{~cm}^{3}$ \\
\hline & Recipient GRBW ratio: & 1.27 \\
\hline Anatomic imaging: & \multicolumn{2}{|c|}{$\begin{array}{l}\text { Hepatic Veins: Conventional anatomy of the hepatic veins, small hepatic vein draining the 4th segment that } \\
\text { joins the left hepatic vein shortly before the inferior vena cava confluence } \\
\text { Hepatic Artery: Conventional anatomy of the celiac trunk, regularly patent } \\
\text { Portal Vein: Conventional anatomy of the main portal vein and of the intrahepatic portal branches } \\
\text { Biliary Tree: Drainage of the right posterior duct into the choledochus about } 11 \mathrm{~mm} \text { from the confluence of } \\
\text { the bile duct draining the right anterior sectors into the left duct }\end{array}$} \\
\hline \multicolumn{3}{|l|}{ Urata formula: } \\
\hline BSA: & & $1.87 \mathrm{~m}^{2}$ \\
\hline Standard liver volume: & & $1326.09 \mathrm{~cm}^{3}$ \\
\hline Minimal donor volume: & & $464.13 \mathrm{~cm}^{3}$ \\
\hline \multicolumn{3}{|l|}{ Vauthey formula: } \\
\hline (a) With BSA (Mosteller) & & $1.90 \mathrm{~m}^{2}$ \\
\hline Total liver volume: & & $1611.87 \mathrm{~cm}^{3}$ \\
\hline Minimal donor volume: & & $564.15 \mathrm{~cm}^{3}$ \\
\hline (b) With body weight: & & $76.80 \mathrm{~kg}$ \\
\hline Total liver volume: & & $1613.37 \mathrm{~cm}^{3}$ \\
\hline Minimal donor volume: & & $564.68 \mathrm{~cm}^{3}$ \\
\hline
\end{tabular}

CT computed tomography, BSA body surface area; BMI body mass index; GRBW graft weight-to-recipient body weight ratio

At this regard we should also take in consideration the possibility to use the new generation absorbable stent developed recently which can be placed through endoscopic or surgical approach [29-31].

The technique we describe in the video, allow to keep the biliary anastomoses protected and patent without having the risk of creating cholestasis and the need of invasive additional procedure.

\section{Supplementary Information}

The online version contains supplementary material available at https://doi. org/10.1186/s12893-020-01045-7.

Additional file 1: Video. Imaging evaluation and surgical maneuvers.

\section{Abbreviations}

LDLT: Living donor liver transplantation; MELD: Model of End-stage Liver Disease; TIPSS: Transjugular Intrahepatic Portal-Systemic Shunt; MRCP: Magnetic resonance cholangiopancreatography.

\section{Authors' contributions}

SG, SC, SLP, DC, and FDF were the involved in the liver transplant. SG, AT, DP, $S C, S L P, P B, C R$, and DC were surgeons who cared for the patient in the postoperative setting and followed up on the patient upon discharge. SG obtained informed consent from the patient for the publication and wrote the first draft of the case report. SG and DP edited the manuscript. SG, AT, and FDF edited the video. All authors have read and approved the final manuscript.

\section{Funding}

No funding was required nor obtained for this case report.

\section{Availability of data and materials}

The datasets used and/or analysed during the current study are available from the corresponding author on reasonable request. 


\section{Ethics approval and consent to participate}

The research has been performed in accordance with the Declaration of Helsinki. The name of the ethics committee that approved the study is sectional Ethical Committee IRCCS ISMETT, and the committee's reference number is: IRRB/42/16. Informed consents were obtained from the patients to use them medical records for research and publication, and attached as Related Files.

\section{Consent for publication.}

Written consent was obtained from the patient and institution.

\section{Competing interests}

The authors declare no competing interests.

\begin{abstract}
Author details
${ }^{1}$ Department for the Treatment and Study of Abdominal Diseases and Abdominal Transplantation, IRCCS-ISMETT (Istituto Di Ricovero E Cura a Carattere Scientifico-Istituto Mediterraneo Per I Trapianti E Terapie ad alta specializzazione) UPMC (University of Pittsburgh Medical Center) Italy, Via E. Tricomi 5, 90127 Palermo, Italy. ${ }^{2}$ Department of Surgery and Surgical and Medical Specialties, University of Catania, Catania, Italy.
\end{abstract}

Received: 12 November 2020 Accepted: 28 December 2020

Published online: 19 January 2021

\section{References}

1. Gruttadauria S, di Francesco F, Vizzini GB, Luca A, Spada M, Cintorino D, Petri SL, Pietrosi G, Pagano D, Gridelli B. Early graft dysfunction following adult-to-adult living-related liver transplantation: predictive factors and outcomes. World J Gastroenterol. 2009;15(36):4556-60. https://doi. org/10.3748/wjg.15.4556.

2. Bhangui $P$, Saha $S$. The high-end range of biliary reconstruction in living donor liver transplant. Curr Opin Organ Transplant. 2019;24(5):623-30. https://doi.org/10.1097/MOT.0000000000000693.

3. Chok KS, Lo CM. Systematic review and meta-analysis of studies of biliary reconstruction in adult living donor liver transplantation. ANZ J Surg. 2017;87(3):121-5. https://doi.org/10.1111/ans.13827.

4. Lin TS, Co JS, Chen CL, Ong AD. Optimizing biliary outcomes in living donor liver transplantation: evolution towards standardization in a highvolume center. Hepatobiliary Pancreat Dis Int. 2020;19(4):324-7. https:// doi.org/10.1016/j.hbpd.2020.06.012.

5. Gruttadauria S, Doria C, Cintorino D, Singhal D, Verzaro R, Foglieni CS, Marino IR, Fung JJ. Outcomes in 139 cases of biliary tract reconstructions from a transplant surgery center. Exp Clin Transplant. 2003;1(2):73-8.

6. Arikan T, Emek E, Bozkurt B, Mammadov E, Ceyhan O, Sahin T, Dibekoglu C, Serin A, Aydin U, Tokat Y. Does multiple bile duct anastomosis in living donor liver transplantation affect the postoperative biliary complications? Transplant Proc. 2019;51(7):2473-7. https://doi.org/10.1016/j.transproce ed.2019.01.160.

7. You MS, Paik WH, Choi YH, Shin BS, Lee SH, Ryu JK, Kim YT, Suh KS, Lee KW, Yi NJ, Hong SK. Optimal biliary drainage for patients with biliary anastomotic strictures after right lobe living donor liver transplantation. Liver Transpl. 2019;25(8):1209-19. https://doi.org/10.1002/lt.25472.

8. Sato T, Kogure H, Nakai Y, Hamada T, Takahara N, Mizuno S, Kawaguchi Y, Akamatsu N, Kaneko J, Hasegawa K, Tada M, Tsujino T, Isayama H, Koike K. Long-term outcomes of endoscopic treatment for duct-to-duct anastomotic strictures after living donor liver transplantation. Liver Int. 2019;39(10):1954-63. https://doi.org/10.1111/liv.14219.

9. Suh KS, Choi SH, Yi NJ, Kwon CH, Lee KU. Biliary reconstruction using the cystic duct in right lobe living donor liver transplantation. J Am Coll Surg. 2004;199(4):661-4. https://doi.org/10.1016/j.jamcollsurg.2004.05.278.

10. Asonuma K, Okajima H, Ueno M, Takeichi T, Zeledon Ramirez ME, Inomata Y. Feasibility of using the cystic duct for biliary reconstruction in rightlobe living donor liver transplantation. Liver Transpl. 2005;11(11):1431-4. https://doi.org/10.1002/lt.20496.

11. Gruttadauria S, Pagano D, di Francesco F, Foglio A, Cammà C, Di Marco V, Petridis I, Cintorino D. Adult to adult living donor liver transplantation in recipients with Low MELD: a strategy intended to overcome donor shortage. Dig Dis Sci. 2020. https://doi.org/10.1007/s10620-020-06522-w.
12. Jung DH, Ikegami T, Balci D, Bhangui P. Biliary reconstruction and complications in living donor liver transplantation. Int J Surg. 2020;82S:138-44. https://doi.org/10.1016/j.ijsu.2020.04.069.

13. Gruttadauria S, Pagano D, Liotta R, Tropea A, Tuzzolino F, Marrone G, Mamone G, Marsh JW, Miraglia R, Luca A, Vizzini G, Gridelli BG. Liver volume restoration and hepatic microarchitecture in small-for-size syndrome. Ann Transplant. 2015;20:381-9. https://doi.org/10.12659/ AOT.894082.

14. Kollmann D, Goldaracena N, Sapisochin G, Linares I, Selzner N, Hansen BE, Bhat M, Cattral MS, Greig PD, Lilly L, McGilvray ID, Ghanekar A, Grant DR, Selzner M. Living donor liver transplantation using selected grafts with 2 bile ducts compared with 1 bile duct does not impact patient outcome. Liver Transpl. 2018;24(11):1512-22. https://doi.org/10.1002/lt.25197.

15. Pagano D, Cintorino D, Li Petri S, Paci M, Tropea A, Ricotta C, Bonsignore P, Saffioti MC, Spada M, Miraglia R, Gridelli BG, Gruttadauria S. Intraoperative contrast cholangiography in living donor liver transplantation: the ISMETT experience. Transplant Proc. 2015;47(7):2159-60. https://doi. org/10.1016/j.transproceed.2014.11.069.

16. Tang W, Qiu JG, Cai Y, Cheng L, Du CY. increased surgical complications but improved overall survival with adult living donor compared to deceased donor liver transplantation: a systematic review and metaanalysis. Biomed Res Int. 2020. https://doi.org/10.1155/2020/1320830.

17. Colquhoun SD. The realities of liver transplantation and biliary anastomosis-heroes, heroics, heels, and healing. JAMA Surg. 2019;154(5):440. https ://doi.org/10.1001/jamasurg.2018.5538.

18. Kaldas FM, Korayem IM, Russell TA, Agopian VG, Aziz A, DiNorcia J, Farmer DG, Yersiz H, Hiatt JR, Busuttil RW. Assessment of anastomotic biliary complications in adult patients undergoing high-acuity liver transplant. JAMA Surg. 2019;154(5):431-9. https://doi.org/10.1001/jamasurg.2018.5527.

19. Pamecha V, Sasturkar SV, Sinha PK, Mohapatra N, Patil N. Biliary reconstruction in adult living donor liver transplantation: the all-knots-outside technique. Liver Transpl. 2020. https://doi.org/10.1002/lt.25862.

20. Mercado MA, Chan C, Orozco H, Cano-Gutiérrez G, Chaparro JM, Galindo E, Vilatobá M, Samaniego-Arvizu G. To stent or not to stent bilioenteric anastomosis after iatrogenic injury: a dilemma not answered? Arch Surg. 2002;137(1):60-3. https://doi.org/10.1001/archsurg.137.1.60.

21. Cameron JL, Skinner DB, Zuidema GD. Long term transhepatic intubation for hilar hepatic duct strictures. Ann Surg. 1976;183(5):488-95. https://doi. org/10.1097/00000658-197605000-00005.

22. Cameron JL, Gayler BW, Zuidema GD. The use of silastic transhepatic stents in benign and malignant biliary strictures. Ann Surg. 1978;188(4):552-61. https://doi.org/10.1097/00000658-197810000-00012

23. Jarnagin WR, Blumgart LH. Operative repair of bile duct injuries involving the hepatic duct confluence. Arch Surg. 1999;134(7):769-75. https://doi. org/10.1001/archsurg.134.7.769.

24. Gruttadauria S, Vasta F, Minervini MI, Piazza T, Arcadipane A, Marcos A Gridelli B. Significance of the effective remnant liver volume in major hepatectomies. Am Surg. 2005;71(3):235-40.

25. Maruzzelli L, Miraglia R, Caruso S, Milazzo M, Mamone G, Gruttadauria S, Spada M, Luca A, Gridelli B. Percutaneous endovascular treatment of hepatic artery stenosis in adult and pediatric patients after liver transplantation. Cardiovasc Intervent Radiol. 2010;33(6):1111-9. https://doi. org/10.1007/s00270-010-9848-4.

26. Marrone G, Crino'F, Caruso S, Mamone G, Carollo V, Milazzo M, Gruttadauria S, Luca A, Gridelli B. Multidisciplinary imaging of liver hydatidosis. World J Gastroenterol. 2012;18(13):1438-47. https://doi.org/10.3748/wjg. v18.i13.1438.

27. Gruttadauria S, Saint Georges Chaumet M, Pagano D, Marsh JW, Bartoccelli C, Cintorino D, Arcadipane A, Vizzini G, Spada M, Gridelli B. Impact of blood transfusion on early outcome of liver resection for colorectal hepatic metastases. J Surg Oncol. 2011;103(2):140-7. https://doi. org/10.1002/jso.21796.

28. Gruttadauria S, Pagano D, Petridis I, Vizzini G, Volpes R, Grossi PA, Gridelli B. Hepatitis C virus infection in a living-related liver donor. Am J Transplant. 2010;10(1):191. https://doi.org/10.1111/j.1600-6143.2009.02874.x.

29. Janousek L, Maly S, Oliverius M, Kocik M, Kucera M, Fronek J. Bile duct anastomosis supplied with biodegradable stent in liver transplantation: the initial experience. Transplant Proc. 2016;48(10):3312-6. https://doi. org/10.1016/j.transproceed.2016.09.039. 
30. Girard E, Chagnon G, Broisat A, Dejean S, Soubies A, Gil H, Sharkawi T, Boucher F, Roth GS, Trilling B, Nottelet B. From in vitro evaluation to human postmortem pre-validation of a radiopaque and resorbable internal biliary stent for liver transplantation applications. Acta Biomater. 2020;106:70-81. https://doi.org/10.1016/j.actbio.2020.01.043.

31. Girard E, Chagnon G, Moreau-Gaudry A, Letoublon C, Favier D, Dejean S, Trilling B, Nottelet B. Evaluation of a biodegradable PLA-PEG-PLA internal biliary stent for liver transplantation: in vitro degradation and mechanical properties. J Biomed Mater Res B Appl Biomater. 2020. https://doi. org/10.1002/jbm.b.34709.

\section{Publisher's Note}

Springer Nature remains neutral with regard to jurisdictional claims in published maps and institutional affiliations.
Ready to submit your research? Choose BMC and benefit from:

- fast, convenient online submission

- thorough peer review by experienced researchers in your field

- rapid publication on acceptance

- support for research data, including large and complex data types

- gold Open Access which fosters wider collaboration and increased citations

- maximum visibility for your research: over $100 \mathrm{M}$ website views per year

At BMC, research is always in progress.

Learn more biomedcentral.com/submissions 